Article

\title{
Cadmium Pathways in Snails Follow a Complementary Strategy between Metallothionein Detoxification and Auxiliary Inactivation by Phytochelatins
}

\author{
Martin Dvorak ${ }^{1}$, Raimund Schnegg ${ }^{1}$, Michael Niederwanger ${ }^{1}\left(\mathbb{D}\right.$, Veronika Pedrini-Martha ${ }^{1}{ }^{(\mathbb{D})}$ \\ Peter Ladurner ${ }^{1}$, Herbert Lindner ${ }^{2}$, , Leopold Kremser ${ }^{2}$, Reinhard Lackner ${ }^{1, *}$ (]) \\ and Reinhard Dallinger ${ }^{1, *}$ \\ 1 Institute of Zoology and Center for Molecular Biosciences Innsbruck, University of Innsbruck, \\ Technikerstr. 25, A-6020 Innsbruck, Austria; martin.dvorak@uibk.ac.at (M.D.); \\ raimund.schnegg@uibk.ac.at (R.S.); michael.niederwanger@uibk.ac.at (M.N.); \\ veronika.pedrini-martha@uibk.ac.at (V.P.-M.); peter.ladurner@uibk.ac.at (P.L.) \\ 2 Institute of Clinical Biochemistry, Innsbruck Medical University, Biocenter, Innrain 80, A-6020 Innsbruck, \\ Austria; herbert.lindner@i-med.ac.at (H.L.); leopold.kremser@i-med.ac.at (L.K.) \\ * Correspondence: reinhard.lackner@uibk.ac.at (R.L.); reinhard.dallinger@uibk.ac.at (R.D.)
}

Received: 7 November 2019; Accepted: 14 December 2019; Published: 18 December 2019

\begin{abstract}
Metal detoxification is crucial for animals to cope with environmental exposure. In snails, a pivotal role in protection against cadmium (Cd) is attributed to metallothioneins (MTs). Some gastropod species express, in a lineage-specific manner, Cd-selective MTs devoted exclusively to the binding and detoxification of this single metal, whereas other species of snails possess non-selective MTs, but still show a high tolerance against $C d$. An explanation for this may be that invertebrates and in particular snails may also synthetize phytochelatins (PCs), originally known to be produced by plants, to provide protection against metal or metalloid toxicity. Here we demonstrate that despite the fact that similar mechanisms for $\mathrm{Cd}$ inactivation exist in snail species through binding of the metal to MTs, the actual detoxification pathways for this metal may follow different traits in a species-specific manner. In particular, this depends on the detoxification capacity of MTs due to their Cd-selective or non-specific binding features. In the terrestrial slug Arion vulgaris, for example, Cd is solely detoxified by a Cd-selective MT isoform (AvMT1). In contrast, the freshwater snail Biomphalaria glabrata activates an additional pathway for metal inactivation by synthesizing phytochelatins, which compensate for the insufficient capacity of its non-selective MT system to detoxify $\mathrm{Cd}$. We hypothesize that in other snails and invertebrate species, too, an alternative inactivation of the metal by PCs may occur, if their MT system is not Cd-selective enough, or its Cd loading capacity is exhausted.
\end{abstract}

Keywords: Mollusca; Gastropoda; slug; snail; cadmium tolerance; cadmium accumulation; cadmium binding selectivity; specificity; detoxification capacity; phytochelatin synthase

\section{Introduction}

Snails (Gastropoda) represent one of the most species-rich phyla of the animal kingdom, playing an important role in marine, freshwater, and terrestrial ecosystems [1,2]. With a close dependence on their chemical environment and a mostly limited mobility, regulation and detoxification of non-essential toxic metals, like cadmium (Cd), is crucial for their growth and survival [3,4]. An important role in the detoxification of this metal is attributed to the wide-spread family of metallothioneins (MTs). These are mainly low-molecular sized proteins containing a high amount of Cys residues involved in 
binding of transition metal ions such as $\mathrm{Zn}^{2+}, \mathrm{Cd}^{2+}$, and $\mathrm{Cu}^{+}$[5]. The amino acid sequence of MTs is characterized by repeat motifs of Cys residues such as Cys-X-Cys or Cys- $X-X-C y s$, where $X$ is any amino acid except cysteine [6]. These motifs play a central role in formation of metal complexes [7], where metals are bound to the MT polypeptide in firm clusters of metal-thiolate bonds through the sulphur atoms provided by the various Cys residues [8]. Vertebrate and most other animal MTs exhibit a dumbbell-shaped three-dimensional structure with two metal binding domains, each containing a rigid core holding three to four metal ions [9]. Some snail species like Littorina littorea and Pomatias elegans, express three-domain MTs [10,11], which were not known until recently.

Owing to their unique metal binding features, MTs are primarily involved in capture and release of metal ions, serving physiological tasks related to storage, delivery, and inactivation of essential trace metals, as well as detoxification of non-essential metal ions [5,12-14]. In most animal MTs, the metal composition of metal thiolate clusters is promiscuous, although some difference in metal selectivity may exist between the protein domains [15-17]. Thus, under in vivo conditions most MTs exhibit a hetero-metallic and metamorphic composition, with low preferences for a defined metal species, if any at all [18-20]. Hence most metal-MT complexes may comprise a variable number of metal ions, even a mixture of different metal species (e.g., $\mathrm{Zn}^{2+}$ together with $\mathrm{Cu}^{+}$) [5]. In contrast, many species of Gastropoda possess metal-selective MT isoforms and variants, which form homometallic complexes with distinct transition metal ions. For example, some snails express $\mathrm{Cu}$ - and $\mathrm{Cd}$-selective MT isoforms [21] that are prevalently devoted to physiological functions related to the respective metal ion species bound. Consequently, Cd-selective MT isoforms are involved in the inactivation and detoxification of $\mathrm{Cd}^{2+}$ ions in snail soft tissues [22]. The detoxification capacity of these isoforms is enhanced by the rapid Cd-induced transcription of their genes [10,23].

In addition to MT expression, some snails also possess the capacity to synthesize phytochelatins (PCs) in response to metal exposure [24]. PCs are cysteine-rich non-ribosomal peptides produced from glutathione (GSH) by the action of the enzyme phytochelatin synthase, which also plays a role in the catabolism of GSH conjugates in plants [25]. GSH is the major thiol compound produced by animals, plants, and bacteria. It is typically present at millimolar concentrations within cells and can constitute up to $90 \%$ of non-protein thiols [26]. Along with GSH, PCs are involved in protective intracellular functions such as oxidative stress defence, regulation of intracellular trace element concentrations and metal detoxification [27]. The general structure of PC peptides is ( $\gamma$-GluCys) ${ }_{n}$ Gly where $n$ can assume a value between 2 to 11 . They are wide-spread in plants [28], although more recent studies have documented their presence in different invertebrate animals, too [24,29], including the freshwater snail Lymnaea stagnalis [24]. The nematode Caenorhabditis elegans can detoxify $\mathrm{Cd}^{2+}$ and probably some other metal and metalloid ions by production of PCs [30], through the activity of phytochelatin synthase [31]. The phytochelatin synthase gene has a wide phylogenetic distribution across almost all of the animal tree of life. Available data until now suggest, however, that the occurrence of phytochelatin synthase is patchy, meaning that some members of particular taxonomic groups may contain the phytochelatin synthase gene, and some of those do synthesize PCs in response to potentially toxic elements [24].

How and if PCs in invertebrates interact with the function of MTs remains to be elucidated, and the temporal, spatial, and metal specificity of the two systems is still unknown. In invertebrate animals both systems coexist and both systems may function as scavengers in a first defence line of metal detoxification [32].

In our previous studies we have shown that $\mathrm{Cd}$ detoxification in snails is mainly based on the metal-binding capacity of MTs [33-35]. However, the efficiency of Cd detoxification may depend on the degree of their Cd selectivity. Some snails like marine littorinids and terrestrial helicids possess highly Cd-selective MTs with a high response and binding capacity against $C d$ exposure $[21,23,36]$, whereas other species, particularly from freshwater environments, express poorly responsive, non-selective MTs that bind $\mathrm{Cd}^{2+}$ ions with a much lower degree of efficiency [37]. In some of these species like Lymnaea stagnalis, apparently both detoxification systems (MTs and PCs), co-exist [24,38]. The potential role of PCs and their interaction with the MT system, however, has so far not been considered. In the 
present study we test the hypothesis that both detoxification systems (MTs and PCs) complement each other in detoxification of $\mathrm{Cd}$, depending on the degree of $\mathrm{Cd}$ response and selectivity of the respective MT isoforms. We compare two species of gastropods, Arion vulgaris and Biomphalaria glabrata, and their response to Cd exposure. Arion vulgaris possesses an inducible Cd-selective MT (AvMT1) [39], while the second species relies on a non-selective MT that is hardly inducible by Cd exposure [37,40]. We provide evidence that in snails, PCs are ready to take over protection against $\mathrm{Cd}$ impact, if the detoxification capacity of MTs becomes deficient due to lacking metal binding selectivity or oversaturation of their binding capacity.

\section{Results and Discussion}

\subsection{Species-Specific Differences in Cd Uptake and the Role of Metallothioneins}

In spite of the different experimental regimes and uptake routes through food or water in the terrestrial slug Arion vulgaris and the freshwater snail Biomphalaria glabrata, both species strongly accumulated $\mathrm{Cd}$ in their midgut gland upon metal exposure (Figure 1A), reaching concentrations of about 290 (Arion vulgaris) and $350 \mu \mathrm{g} \mathrm{Cd} / \mathrm{g}$ dry wt. (Biomphalaria glabrata), respectively. Compared to $\mathrm{Cd}$ control values of about $27 \mu \mathrm{g} \mathrm{Cd} / \mathrm{g}$ dry wt. in Arion vulgaris and $3 \mu \mathrm{g} \mathrm{Cd} / \mathrm{g}$ in Biomphalaria glabrata, this corresponds to metal accumulation factors in the midgut gland of about 11 and 116, respectively. At the same time, no mortality was observed in the two species, confirming their high tolerance and detoxification capacity against this highly toxic metal $[37,39]$.
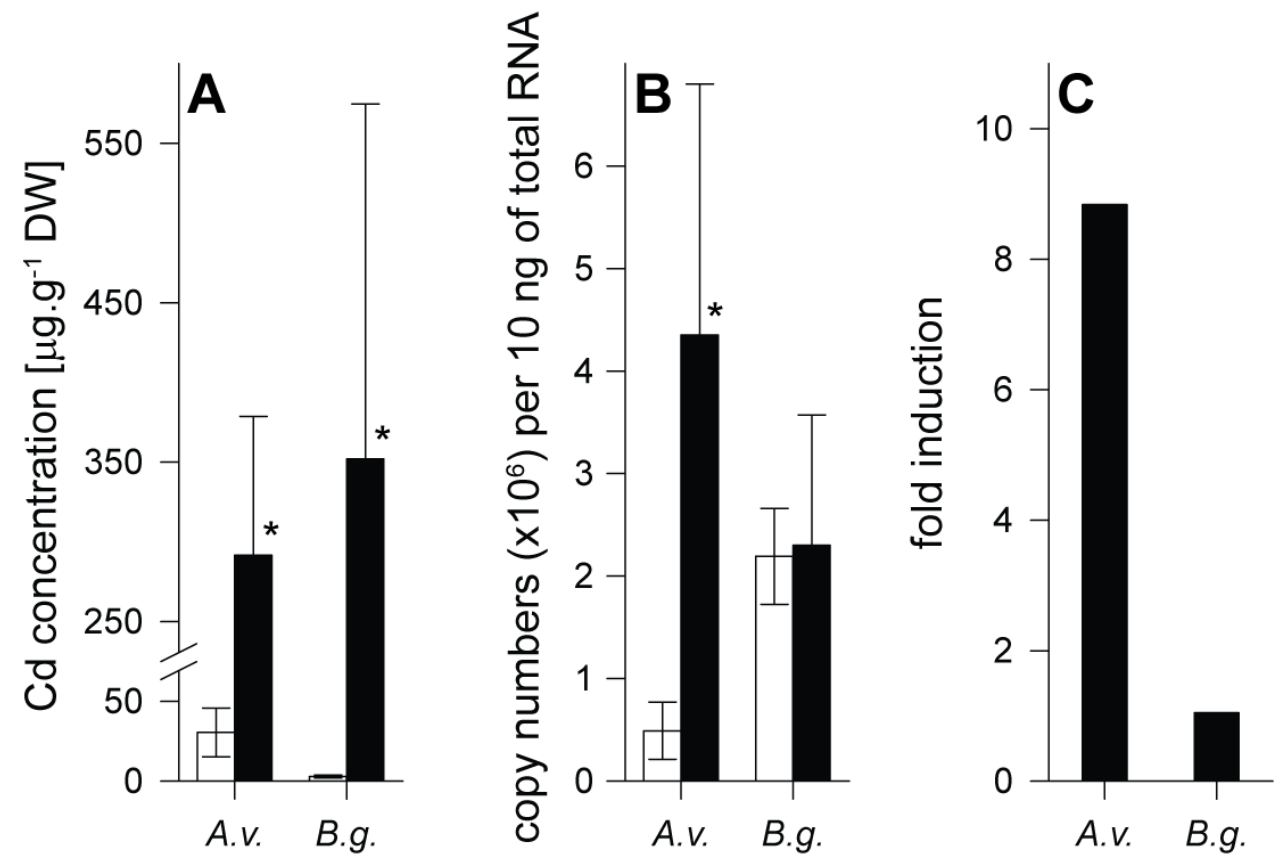

Figure 1. Comparison of control (white columns) and Cadmium (Cd) exposed (black columns) individuals of Arion vulgaris (A.v.) and Biomphalaria glabrata (B.g.). (A) Cd concentrations expressed in $\mu \mathrm{g}$ per $\mathrm{g}$ dry weight (DW), shown in midgut gland of A.v. and B.g. exposed to Cd over a period of 15 days (A.v.) and 14 days (B.g.) (means and standard deviations, $n=3-4$ ). (B) Transcriptional upregulation of MT genes of Arion vulgaris (AvMT1, GenBank: MF155618.1) and Biomphalaria glabrata (GenBank: XM_013225031), expressed as mRNA copy numbers per 10 ng of total RNA after Cd exposure over a period of 15 days (A.v.) and 14 days (B.g.) (means and standard deviations, $n=5$ ). (C) Transcriptional upregulation of MT genes of A.v. and B.g., expressed as -fold induction (mean values, derived from $\mathbf{B})$. The asterisks indicate significant differences compared to respective control values (Holm-Sidak method of all pairwise multiple comparisons) $\left({ }^{*} p \leq 0.05\right)$. 
In spite of the much stronger Cd accumulation in Biomphalaria glabrata, only in Arion vulgaris a significant transcriptional upregulation (9-fold) of the respective Cd-selective AvMT1 gene occurs (GenBank: MF155618, [39]). In contrast, no detectable upregulation was observed for the unspecific MT gene of Biomphalaria glabrata (GenBank: KT697617, [37]) (Figure 1B,C).

In both species, the $C d$ amount associated to MT under control conditions was below $5 \mu \mathrm{g} / \mathrm{g}$ dry wt. After Cd exposure, however, about 135-145 $\mu \mathrm{g}$ of the metal in the midgut gland of the two species were bound to MT (Figure 2A). If referred to the total Cd concentration in this organ, the percentage fraction of $\mathrm{Cd}$ bound to MT after metal exposure largely differed between the two species. In Arion vulgaris, a predominant portion of the metal (75\%) was bound to the metal-specific MT (AvMT1), whereas only $32 \%$ of the metal was associated with the non-specific MT in the midgut gland of Biomphalaria glabrata (Figure 2B). Thus concomitantly with the differential Cd-dependent MT gene upregulation pattern of the two species (Figure 1B,C), the Cd-selective AvMT1 of Arion vulgaris appears to possess a much higher detoxification potential for $\mathrm{Cd}$ than the unspecific MT of Biomphalaria glabrata. Since both species exhibit a considerable tolerance towards $\mathrm{Cd}$ upon metal exposure (see above), this suggests that the lacking inactivation capacity for Cd by the MT system in Biomphalaria glabrata must be compensated by an additional mechanism of detoxification.
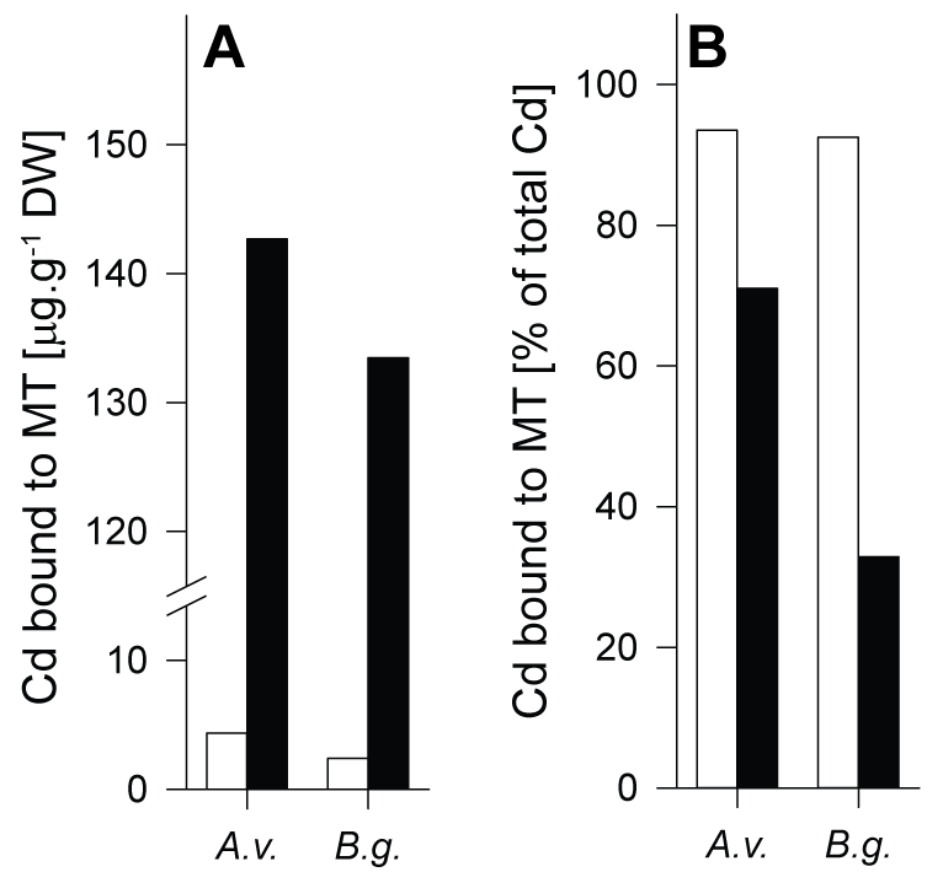

Figure 2. Cadmium (Cd) concentrations related to metallothionein (MT) fractions after gel chromatography separation from midgut gland extracts of control (white columns) and Cd-exposed (black columns) Arion vulgaris (A.v.) and Biomphalaria glabrata (B.g.), expressed as Cd bound to MT (in $\mu \mathrm{g} / \mathrm{g}$ DW, as above) (A); and as percentage fraction (\%) of total Cd bound to MT (B).

\subsection{Transcriptomic Analyses of Gastropod Phytochelatin Synthase mRNA Transcripts}

Following the discovery of PCs in a snail [24], a primary candidate for such an additional mechanism would be scavenging of Cd by PCs. While MTs are metal-binding proteins that are encoded by their respective genes, PCs are peptides that are metabolically synthesized through the activity of the enzyme phytochelatin synthase. A screening of our transcriptomic databases revealed the presence of phytochelatin synthase genes in all species for which transcriptomes were available. In addition, a search in NCBI databases uncovered additional snail phytochelatin synthase genes (Table 1). Overall, this suggests that phytochelatin synthase genes are present in probably all major gastropod clades. However, Table 1 does not specify whether the respective phytochelatin synthase enzymes are actually active. 
Table 1. The presence of putative phytochelatin synthase mRNAs in transcriptomes of different gastropod species. Complete sequences include start and stop codon.

\begin{tabular}{|c|c|c|c|c|c|}
\hline Id & Name & Clade & Habitat & Source & Reading Frame \\
\hline M.c. & Marisa cornuarietis & Caenogastropoda & Freshwater & This study & Complete \\
\hline P.b. & Pomacea bridgesii & Caenogastropoda & Freshwater & This study & Complete \\
\hline P.c. & Pomacea canaliculata & Caenogastropoda & Freshwater & $\begin{array}{c}\text { NCBI } \\
\text { XP_025099563.1 }\end{array}$ & Complete \\
\hline A.h. & $\begin{array}{c}\text { Anentome } \\
\text { helena }\end{array}$ & Caenogastropoda & Freshwater & This study & Complete \\
\hline P.e. & Pomatias elegans & Caenogastropoda & Terrestrial & This study & Missing stop codon \\
\hline A.c. & Aplysia californica & Heterobranchia & Marine & $\begin{array}{c}\text { NCBI } \\
\text { XM_005110788.2 }\end{array}$ & Complete \\
\hline E.c. & Elysia crispata & Heterobranchia & Marine & This study & Complete \\
\hline B.g. & Biomphalaria glabrata & $\begin{array}{c}\text { Heterobranchia } \\
\text { Hygrophila }\end{array}$ & Freshwater & $\begin{array}{c}\text { NCBI } \\
\text { XM_013214798.1 }\end{array}$ & Complete \\
\hline G.t. & Galba truncatula & $\begin{array}{l}\text { Heterobranchia } \\
\text { Hygrophila }\end{array}$ & Freshwater & $\begin{array}{l}\text { Romiguier et al. } \\
\text { (2014) [41] }\end{array}$ & Complete \\
\hline L.m. & Limax maximus & $\begin{array}{l}\text { Heterobranchia } \\
\text { Stylommatophora }\end{array}$ & Terrestrial & This study & Complete \\
\hline C.a. & Cornu aspersum & $\begin{array}{l}\text { Heterobranchia } \\
\text { Stylommatophora }\end{array}$ & Terrestrial & This study & Complete \\
\hline H.p. & Helix pomatia & $\begin{array}{l}\text { Heterobranchia } \\
\text { Stylommatophora }\end{array}$ & Terrestrial & This study & Complete \\
\hline A.b. & Alinda biplicata & $\begin{array}{l}\text { Heterobranchia } \\
\text { Stylommatophora }\end{array}$ & Terrestrial & This study & Complete \\
\hline A.v. & Arion vulgaris & $\begin{array}{l}\text { Heterobranchia } \\
\text { Stylommatophora }\end{array}$ & Terrestrial & $\begin{array}{c}\text { NCBI } \\
\text { PRJEB7891 }\end{array}$ & $\begin{array}{l}\text { Missing start and } \\
\text { stop codon }\end{array}$ \\
\hline P.v. & Patella vulgata & Patellogastropoda & Marine & This study & Complete \\
\hline N.p. & Neritina pulligera & Neritimorpha & Freshwater & This study & Complete \\
\hline T.l. & Titiscania limacina & $\begin{array}{l}\text { Neritimorpha } \\
\text { Cycloneritimorpha }\end{array}$ & Marine & $\begin{array}{c}\text { NCBI } \\
\text { PRJNA253054 }\end{array}$ & Missing stop codon \\
\hline
\end{tabular}

Phytochelatin synthase was first characterized in plants [42]. When comparing the translated amino acid sequences of phytochelatin synthase from the plant Arabidopsis thaliana (GenBank: AAD41794.1, [43]) with those of the slug Arion vulgaris and the snail Biomphalaria glabrata, a certain degree of homology is obvious. This becomes also apparent upon highlighting the resulting consensus sequence between Arabidopsis thaliana and all available gastropods (Figure 3). On the other hand, the variability within the deduced gastropod phytochelatin synthase sequences follows largely the diversity in gastropod systematics (Figure S1).

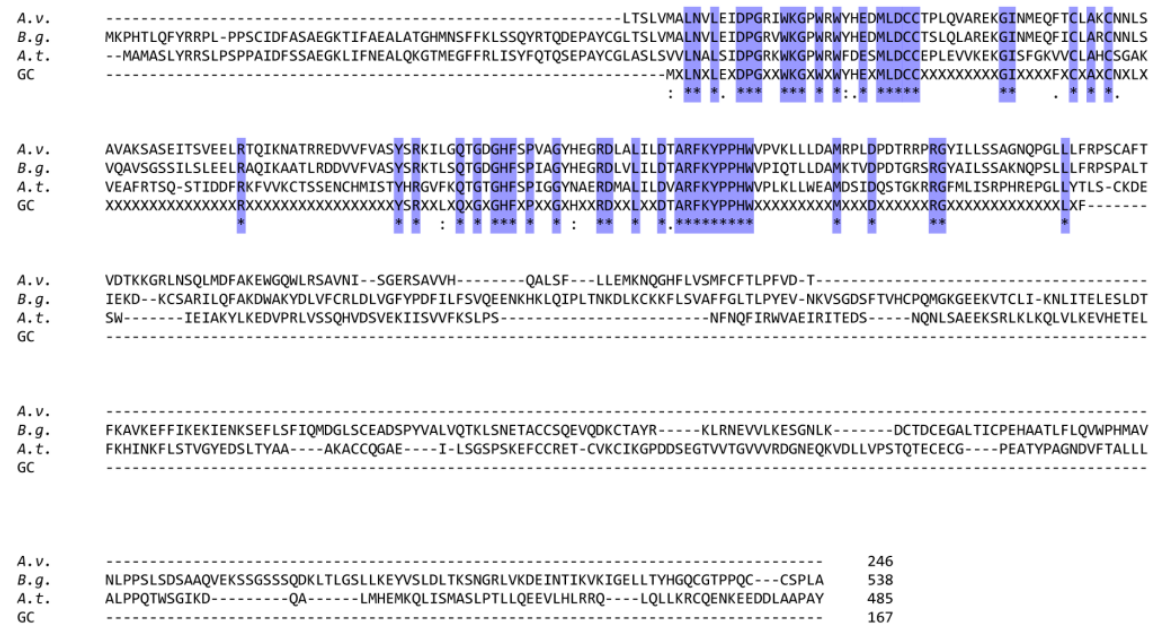

Figure 3. Comparison of amino acid sequences of phytochelatin synthase of Arion vulgaris (A.v.) (incomplete), Biomphalaria glabrata (B.g.), and Arabidopsis thaliana (A.t.), in addition to the respective all available gastropod consensus sequence (GC). Conserved amino acid positions are shadowed in blue. The symbol X means any non-conserved amino acid residue. The symbol "-" stands for alignment gaps. 


\subsection{Metallothioneins versus Phytochelatins}

Both MTs and PCs provide sulphur atoms for metal ion binding through their Cys residues. In Table 2, Cys concentrations in MTs or PCs, expressed as molar Cys equivalents theoretically available for $\mathrm{Cd}^{2+}$ binding, are reported. The data were calculated assuming a binding ratio of $\mathrm{Cys}$ : $\mathrm{Cd}^{2+}$ of $3: 1$ in the Cd-selective AvMT1 of Arion vulgaris [39], 1.83:1 in the unspecific MT of Biomphalaria glabrata [40], and 2:1 in PCs [44,45]. If we consider that the unspecific MT of Biomphalaria glabrata forms, owing to its non-specific binding features for $\mathrm{Cd}^{2+}$, mixed metal complexes involving other metal ions like the divalent $\mathrm{Zn}^{2+}$ and the monovalent $\mathrm{Cu}^{+}$, too [40], it must be assumed that the real availability of Cys for $\mathrm{Cd}^{2+}$ binding in this MT may even be lower than that reported in Table 2. Moreover, the low fraction of total $\mathrm{Cd}^{2+}$ associated with MT in the midgut gland of Biomphalaria glabrata (see Figure 2B) shows that a considerable amount of the metal pool in this snail is kept apart from MT, and would need, if any, additional mechanisms for its detoxification. To compensate for the missing detoxification capacity by MT, Biomphalaria glabrata seems to rely on PC synthesis. Hence, in contrast to Arion vulgaris, a considerable fraction of $\mathrm{Cd}^{2+}$ in Biomphalaria glabrata may be buffered by Cys equivalents provided by PCs (Table 2).

Table 2. Equivalents of cysteine (Cys) expressed in $\mu$ mol per g of dry weight tissue, available for Cd binding in metallothioneins (MT) and phytochelatins (PC).

\begin{tabular}{|c|c|c|c|}
\hline \multirow[t]{2}{*}{ Species } & \multirow{2}{*}{ Treatment } & \multicolumn{2}{|c|}{$\begin{array}{l}\text { Equivalents of Cys [ } \mu \mathrm{mol} / \mathrm{g} \text { Dry wt.] } \\
\text { Available for } \mathrm{Cd}^{2+} \text { Binding }\end{array}$} \\
\hline & & MT & PC \\
\hline \multirow{2}{*}{ Arion vulgaris } & Control & 0.12 & $<0.01$ \\
\hline & Cd-exposed & 3.81 & $<0.01$ \\
\hline \multirow{2}{*}{ Biomphalaria glabrata ${ }^{1}$} & Control & 0.04 & 0.12 \\
\hline & Cd-exposed & 2.18 & 0.55 \\
\hline
\end{tabular}

${ }^{1}$ In Biomphalaria glabrata MT $1 \mathrm{Cd}=1.83$ Cys which equals $66 \%$ of Cys available for Cd binding.

PCs are polymerized in the cellular metabolism from GSH to peptides with different chain lengths (mainly PC2-PC6) through the activity of phytochelatin synthase. In our study, the presence of PCs in the two snail species was assessed through HPLC elution after derivatization to fluorescent thiol-bimane derivatives. As shown by the respective HPLC profile of a PC standard mixture (containing PC2, PC3, PC4, PC5, and PC6) this method allowed detecting all single species between PC2 to PC6 as separate peaks (Figure 4 ).

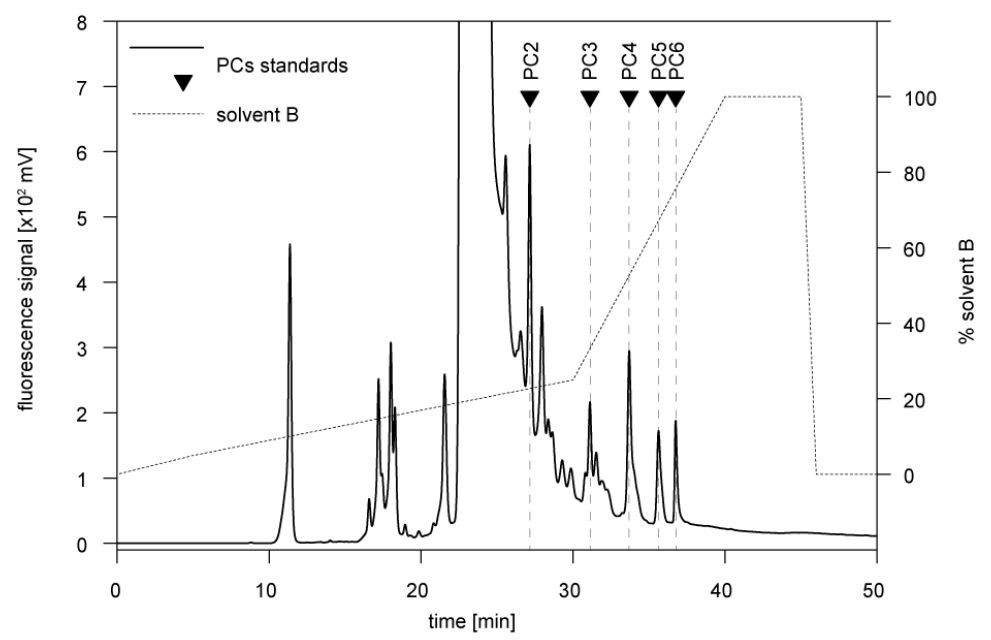

Figure 4. Reversed phase HPLC of a phytochelatin (PC) standard mixture (PC2-PC6) derivatized with monobromobimane, and confirmed by mass spectrometry. Elution times of individual PCs are represented by triangles. 
Although Arion vulgaris accumulates Cd (Figure 1A), only traces of PC2, if any, were observed in the midgut gland of control and Cd-exposed slugs (Figure 5). Instead, all Cys equivalents available for $\mathrm{Cd}^{2+}$ binding and detoxification were provided by the Cd-selective AvMT1 protein [39] (Table 2). The situation was different in Biomphalaria glabrata. Apart from PC2, no other PCs were found in homogenates of control Biomphalaria glabrata. Upon exposure to $\mathrm{Cd}$, however, Biomphalaria glabrata did not induce expression of MT in its midgut gland (Figure $1 \mathrm{~B}, \mathrm{C}$ ), and only about $35 \%$ of $\mathrm{Cd}^{2+}$ were associated with the non-specific MT (Figure 2B). Instead, the snail produced considerable amounts of PCs (Figure 6), reaching altogether molar concentrations of up to $0.55 \mu \mathrm{mol} / \mathrm{g}$ dry wt. Cys equivalents potentially available for $\mathrm{Cd}^{2+}$ binding (Table 2).

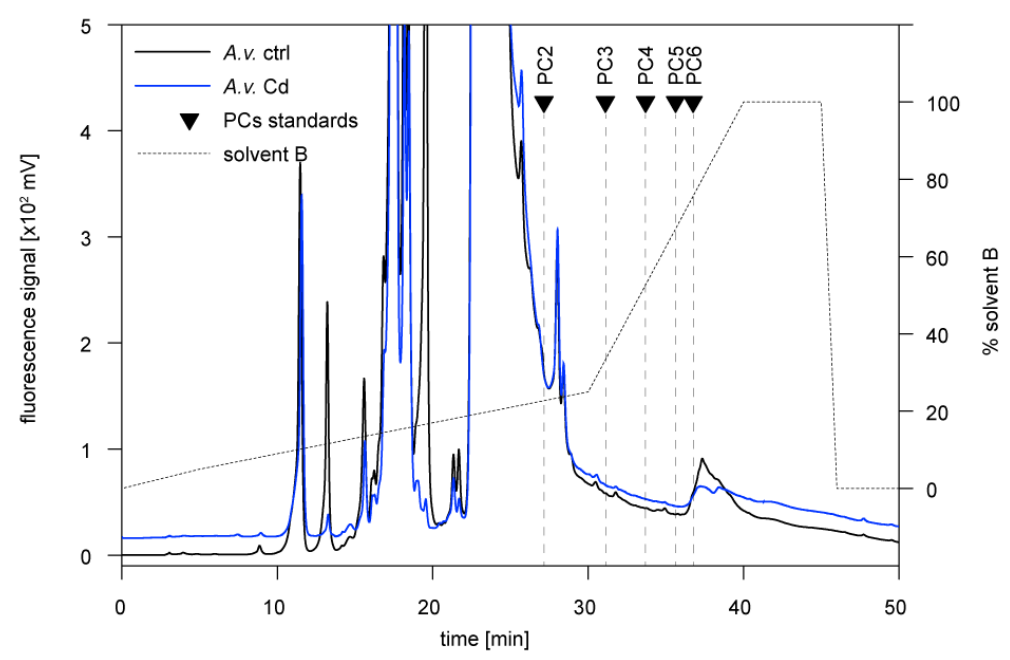

Figure 5. Reversed phase HPLC of Arion vulgaris (A.v.) midgut gland homogenates derivatized with monobromobimane for detection of phytochelatins. Black line: non-exposed animal (ctrl); blue line: Cd-exposed animal for 15 days (Cd). Triangles indicate elution times of standard phytochelatins (PC2-PC6).

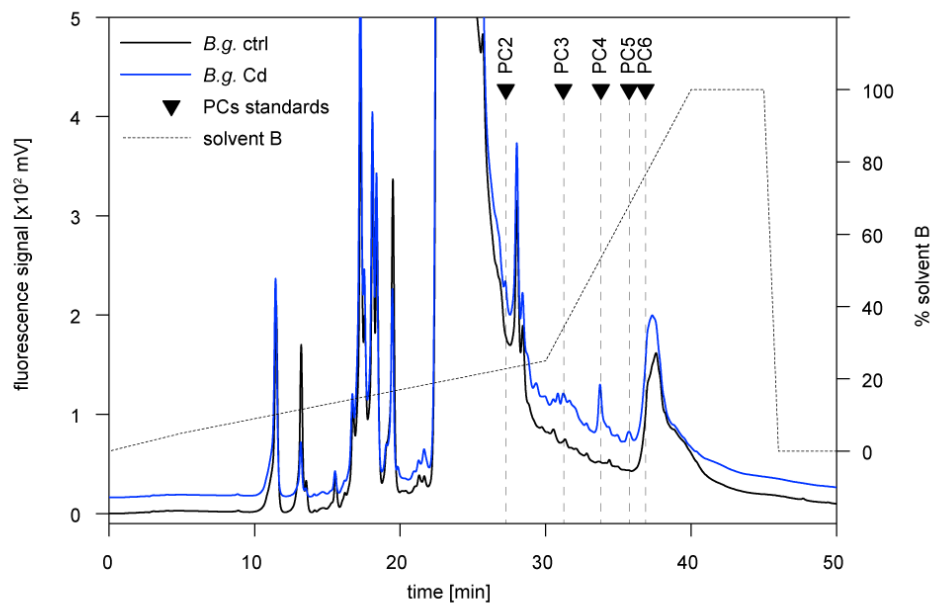

Figure 6. Reversed phase HPLC of Biomphalaria glabrata (B.g.) homogenates derivatized with monobromobimane for detection of phytochelatins. Black line: non-exposed animal (ctrl); blue line: Cd-exposed animal for 14 days (Cd). Triangles indicate elution times of standard phytochelatins (PC2-PC6).

As shown in Table 1, the phytochelatin synthase gene was identified in both, Arion vulgaris and Biomphalaria glabrata, as well as in most other gastropod genomes or transcriptomes studied so far. The phytochelatin synthase gene and its respective transcript seem to be quite conservative and widely distributed throughout the Gastropods (see Figure 3 and Figure S1). However, this does not imply that the phytochelatin synthase enzyme is present, functional or actually involved in Cd detoxification. In a 
recent article by Bundy and colleagues [29], the authors suggested that there is a functional relationship between MTs and PCs in a response-time depending manner.

Our data provide a more extended hypothesis and indicate that in midgut gland cells of snails, GSH is only polymerized to PC peptides in the presence of available $\mathrm{Cd}^{2+}$ and other metal ions in a free form, irrespective of whether this happens due to a delayed response pattern or by exhaustion of the MT detoxification capacity. Indeed, such an assumption would explain the differences found in our study between lacking PC synthesis in Arion vulgaris, in contrast to Biomphalaria glabrata. In this species and probably in many other snails with non-specific MTs [37,40], the detoxification capacity of the MT system may become overstrained, because $\mathrm{Cd}^{2+}$ ions are bound to the protein with poor selectivity. Hence, upon exposure to $\mathrm{Cd}$ beyond a certain threshold, alternative $\mathrm{Cd}^{2+}$ inactivation by complexation to PCs is highly sensible. In the hierarchy of the two detoxification mechanisms, the MT system will probably take the lead over PC synthesis. Different gastropod species express their respective MT isoforms with different expression patterns and intensity depending, among others, on the metal-binding selectivity of their MT isoforms. Pulmonate land snails, for example, possess distinct MT isoforms with metal binding selectivities for different metals [21,46]. Two MT isoforms (AvMT1 and AvMT2) are also present in Arion vulgaris. The AvMT1 isoform is inducible by $\mathrm{Cd}$, being mainly involved in selective detoxification of this metal, whereas the isoform AvMT2 seems to play a minor role in $\mathrm{Cu}$ binding, but is expressed in the slug's midgut gland only in trace amounts, if any [39]. In contrast to terrestrial helicids, many freshwater snails (including Biomphalaria glabrata) do not possess metal-inducible $M T$ genes, nor are the expressed proteins $\mathrm{Cd}$-selective. Apart from Cd selectivity, all MTs (including those of gastropods), bind the metal with a very high affinity, featuring stability constants for $\mathrm{Cd}^{2+}$ of about $2 \times 10^{16}$ (at pH7) [18]. In contrast to MTs, the stability constant of PC-Cd ${ }^{2+}$ complexes is much lower [47]. Hence, the Cd-scavenging function of PCs becomes masked in species where all available $\mathrm{Cd}$ is inactivated by MTs with a high selectivity for this metal. According to this assumption, inactivation of Cd by PCs would occur only in species possessing MTs with a low induction potential and/or without Cd-binding selectivity. Thus overall, phytochelatin synthase becomes involved in a line of detoxification processes where Cd-selective MTs are insufficiently available, lacking, or overstrained in their binding capacity.

\subsection{Methodological Considerations}

Several methods have been reported in the literature to measure concentrations of MTs or metallothionein-like proteins (MTLPs) in animal tissues. One of the most commonly used methods relies on the assessment of thiol groups provided by Cys residues present in MTs or MTLPs by specific chemical reagents. For example, 5,5-dithiobis-2-nitrobenzoic acid (DTNB, Ellmans reagent) gives a yellow colour with $\mathrm{SH}$-containing compounds. In many approaches, the respective tissue is homogenized and fractionated via heat denaturation, organic solvent extraction, and ultrafiltration. By any means this yields low molecular weight protein fractions where the $\mathrm{SH}$ - contents are measured photometrically. This value is synonymized with the MT or MTLP concentration of the tissue [48-50]. However, also PCs give a positive reaction with DTNB. Thus, PCs may hide behind the MTLP measurement with DTNB. Therefore, specificity of this method strongly depends on the efficiency of the organic solvent fractionation. Hence the actual measurement relies on the assumption that all MTs are found in the protein pellet after organic solvent treatment.

Differential pulse polarography (DPP) may be seen as an alternate method to measure $\mathrm{SH}$ - groups in a solute. Depending on the pre-treatment of the sample and the degree of purification this method may give a more or less true measure for the MT concentration in the sample. It has been used to measure the animals' response to environmental pollution [51].

Silver saturation may be used to measure metal binding capacity of homogenates and of MTs [52]. Shortly, all compounds binding metals are saturated with silver, thereby replacing all other metals from the active sites. After removing excess silver and fractionation of the homogenate, silver is usually measured by atomic absorption spectroscopy (AAS). Depending on the quality of this separation, 
the results may be assigned to MTs or MTLPs. This method probably does not distinguish between MTs and PCs. However, it may be useful to detect SH-linked detoxification processes induced by environmental stressors. In the freshwater snail Lymnaea stagnalis, an induction of so-called MTLPs was observed only at very high waterborne concentrations of Cd (1000 $\mu \mathrm{g} \mathrm{L}^{-1}$ [53]), and a similar pattern of induction was also reported from the dogwhelk Nucella lapillus [54,55].

A special case of a metal saturation method is the quantification of MT concentrations by the so-called Chelex assay [56], in which pre-purified MT extracts are saturated with Cd and quantified through the known stoichiometric Cd:MT ratio of snail MTs (6:1) after removal of excess amounts of Cd by Chelex-100 resin [34]. This method does only work for Cd-selective MTs (as in terrestrial snails), and has been successfully applied for environmental monitoring of Cd pollution in soil habitats [57].

Copper replacement of other metals in MTs is a method similar to the above mentioned silver saturation. The CuMT generated by this method exhibits a specific fluorescence, which may be used to quantify MTs in tissues [58]. Alternatively, a Cu saturation method called TTM assay may be applied for quantification of $\mathrm{Cu}$-selective MTs, with calculation of CuMT through the known Cu:MT ratio of Cu-specific MT in snails [34].

An antibody against MT-Class I (Cat. \#18-0133, Zymed, South San Francisco, CA, USA) was used to quantify MTs in the mud snail Ilyanassa obsoleta (now Tritia obsoleta) by ELISA. Upon exposure to Cd at low $(0.5 \mu \mathrm{M})$ or high $(50 \mu \mathrm{M})$ concentrations in brackish water, a huge increase of MT was observed in the whole soft body [59].

As MTs are proteins with a distinct molecular mass, all quantification methods that rely on protein purification prior to quantification may provide more reliable data. For example a simple gel chromatography fractionation followed by measurement of metals in the appropriate fractions gives a suitable approximation of MT concentrations [34,39]. In this case, measurement of the SHconcentration by any of the above mentioned methods should also come to acceptable results [51].

Finally, molecular methods also offer several possibilities to study the expression and induction of the respective $M T$ genes by environmental factors $[37,39,60]$.

\section{Material and Methods}

\subsection{Transcriptome Generation and Screening for Phytochelatins Synthase Genes}

For generating transcriptomes from different gastropods, isolated total RNA from midgut gland $[39,40]$ was sent to the Duke Center for Genomic and Computational Biology (GBC, Duke University, Durham, NC, USA). The RNA was subjected to 125 bp paired-end Illumina sequencing. Raw data were assembled at the Institute of Zoology (University of Innsbruck) using Trinity Version v2.1.1 (GitHub Inc., San Francisco, CA, USA) [61] and provided for analysis on a local TBlast page. For details see Dvorak et al. (2018), Schmielau et al. (2019) [11,39].

All available transcriptomes of gastropods were searched for putative phytochelatin synthase transcripts. We confirmed the presence of the conserved phytochelatin synthase domain of the uncharacterised phytochelatin synthase mRNA sequence (GenBank: XM_013214798) in Biomphalaria glabrata by degenerated primers (forward: TGGAAAGGAYCATGGMGATG; reverse: CCARTGAGGTGGRTATTTAA) (Figure S1) and used it as a template for BLAST analysis in the NCBI database [62,63].

\subsection{Cd Exposure and Tissue Analysis}

Arion vulgaris slugs were collected in close vicinity of Innsbruck and kept on moistened garden soil $\left(18^{\circ} \mathrm{C}, 80 \%\right.$ humidity, and $12 \mathrm{hr}$ light/dark cycles). They were fed on Cd-enriched lettuce leaves for 15 days [39]. Aliquots of midgut gland were taken for MT mRNA quantification by quantitative real-time polymerase chain reaction (qRT PCR). Other aliquots were used for MT separation by gel chromatography and for determination of $\mathrm{Cd}$ tissue accumulation by atomic absorption spectroscopy (AAS). For details see Dvorak et al. (2018) [39]. 
Biomphalaria glabrata snails out of a laboratory culture at the Institute of Zoology, University of Innsbruck, were kept in freshwater aquarium tanks $\left(25^{\circ} \mathrm{C}, 12 \mathrm{~h}\right.$ light/dark cycles) and exposed to a nominal $\mathrm{Cd}$ concentration of $75 \mu \mathrm{g} \cdot \mathrm{L}^{-1}$ [37]. MT gene upregulation and $\mathrm{Cd}$ accumulation were measured in the midgut gland by respective methods, for details see Niederwanger et al. (2017) [37].

\subsection{Determination of Phytochelatins}

Determination of phytochelatins was based on a modified protocol of HPLC with detection of fluorescent thiol-bimane derivatives as described by Kawakami et al. (2006) [27]. Briefly, homogenized midgut gland in 0.1 M TFA, $10 \mathrm{mM}$ EDTA, and $10 \mathrm{mM}$ TCEP $(1: 3 w / v)$ was centrifuged at 13,200 rpm for $20 \mathrm{~min}$ at $4{ }^{\circ} \mathrm{C}$. Fifty microliters of flow-through was pre-derivatized with $150 \mu \mathrm{L}$ of $0.1 \mathrm{M} \mathrm{NH}_{4} \mathrm{HCO}_{3}$ and $50 \mu \mathrm{L} 0.1 \mathrm{M}$ TCEP in $0.1 \mathrm{M} \mathrm{NH}_{4} \mathrm{HCO}_{3}$ for $1 \mathrm{~h}$ at room temperature. The disulphide bonds were converted to sulfhydryls by adding $615 \mu \mathrm{L}$ HEPES buffer and $25 \mu \mathrm{L} 20 \mathrm{mM}$ TCEP and incubation for $10 \mathrm{~min}$ at $45^{\circ} \mathrm{C}$, followed by addition of $10 \mu \mathrm{L}$ of $250 \mathrm{mM}$ monobromobimane and derivatization for $45 \mathrm{~min}$ at $45^{\circ} \mathrm{C}$ in the dark. Derivatization was terminated by adding $100 \mu \mathrm{L} 1 \mathrm{M}$ methanesulfonic acid. The derivatized sample was centrifuged for $1 \mathrm{~min}$ at 13,200 rpm, and $100 \mu \mathrm{L}$ of supernatant was applied to reverse phased HPLC with a LiChrospher 100 RP-18 $(5 \mu \mathrm{m})$ column (Merck, Kenilworth, NJ, USA) thermostatized at $40{ }^{\circ} \mathrm{C}$. The thiol-bimane derivates were eluted on a linear gradient of buffer A consisting of $0.1 \%$ TFA and buffer B consisting of $0.1 \%$ TFA in acetonitrile $(0 \%-5 \%$ B for $0-5$ $\min , 5 \%-25 \%$ B for $5-30 \mathrm{~min}$, and $25 \%-100 \%$ for $30-40 \mathrm{~min}$ ) at a flow rate $1 \mathrm{~mL} \cdot \mathrm{min}^{-1}$. Fluorimetric detection was achieved with $380 \mathrm{~nm}$ (excitation) and $470 \mathrm{~nm}$ (emission) wavelengths. The calibration curve was obtained with a mixture containing $5 \mu \mathrm{g}$ of each (PC2-PC6) of phytochelatin standards derivatized in the same way as the samples. HPLC fractions were manually collected and provided for MS analysis to confirm individual phytochelatin species.

\subsection{Mass Spectroscopy}

Samples were analysed using an UltiMate 3000 RSCLnano-HPLC system coupled to a Q Exactive HF mass spectrometer (both Thermo Scientific, Bremen, Germany) equipped with a Nanospray Flex ionization source. The PCs were separated on a homemade fritless fused-silica micro-capillary column $(100 \mu \mathrm{m}$ i.d. $\times 280 \mu \mathrm{m}$ o.d. $\times 19 \mathrm{~cm}$ length) packed with $2.4 \mu \mathrm{m}$ reversed-phase C18 material. Solvents for HPLC were $0.1 \%$ formic acid (solvent $\mathrm{A}$ ) and $0.1 \%$ formic acid in $85 \%$ acetonitrile (solvent $\mathrm{B}$ ). The gradient profile was as follows: $0-4 \mathrm{~min}, 4 \% \mathrm{~B} ; 4-57 \mathrm{~min}, 4-35 \% \mathrm{~B} ; 57-62 \mathrm{~min}, 35-100 \% \mathrm{~B}$, and $62-67 \mathrm{~min}, 100 \% \mathrm{~B}$. The flow rate was $300 \mathrm{~nL} \cdot \mathrm{min}^{-1}$. The Q Exacitve HF mass spectrometer was operating in the data dependent mode selecting the top 10 most abundant isotope patterns from the survey scan with an isolation window of 1.6 mass-to-charge ratio $(\mathrm{m} / \mathrm{z})$. Survey full scan MS spectra were acquired from 200 to $2000 \mathrm{~m} / \mathrm{z}$ at a resolution of 60,000 with a maximum injection time (IT) of $120 \mathrm{~ms}$, and automatic gain control (AGC) target 1e6. The PCs were identified by comparing the retention time and mass of the detected peaks in the chromatograms of standard PCs and samples.

\subsection{Calculation of $C d$ Fractions Bound to $M T$ and to $P C$}

Cadmium associated to MTs was calculated as a sum of Cd concentrations from GPC fractions in the MT range per $\mathrm{g}$ of dry weight tissue. For Cys equivalents available for $\mathrm{Cd}$ binding we assumed $100 \%$ saturation in Arion vulgaris CdMT, resulting in Cys:Cd ratio of 3:1. In unspecific Biomphalaria glabrata MT we assumed up to $66 \%$ saturation resulting in 1.83:1 Cys:Cd ratio. Similarly for PCs, values refer to sum of individual PC concentrations per $\mathrm{g}$ of dry weight tissue.

\subsection{Statistics}

Relevant statistical analysis was performed in Sigmaplot 12.5 (SYSTAT software, San Jose, CA, USA)(for details see Dvorak et al. (2018) [39] and Niederwanger et al. (2017) [37]). 


\section{Conclusions}

In most animals, MTs play a pivotal role in regulation of transition metals and detoxification of $\mathrm{Cd}$, in particular. In spite of this, the actual detoxification mechanisms for $\mathrm{Cd}$ in different animal species may follow distinct pathways, sometimes through additional inactivation of this metal by phytochelatins. In the present study, we show exemplarily that in gastropods, the pathway of $\mathrm{Cd}$ inactivation depends on the detoxification capacity of MTs, in combination with an auxiliary metal complexation by phytochelatins. Upon Cd exposure, the terrestrial slug Arion vulgaris relies exclusively on Cd detoxification by means of a Cd-selective MT isoform (AvMT1) expressed in its midgut gland. In contrast, Cd-exposed individuals of the freshwater snail Biomphalaria glabrata, cope with the metal stress by synthesizing, in addition to an unspecific MT, phytochelatins. We conclude that the activation of the phytochelatin system for Cd inactivation in snails apparently depends on the $\mathrm{Cd}$ binding efficiency and metal selectivity of their MTs. We hypothesize that this pattern could be of general importance for many other invertebrate lineages, too.

Supplementary Materials: Supplementary materials can be found at http://www.mdpi.com/1422-0067/21/1/7/s1. Figure S1: Alignment of diverse gastropods phytochelatin synthase protein sequences. Conserved regions are highlighted in red (throughout all clades), orange (Caenogastropoda) and pink (Heterobranchia). Following species are listed: Marisa cornuarietis (M.c.), Pomacea bridgesii (P.b.), Pomacea canaliculata (P.c.), Anentome helena (A.h.), Pomatias elegans (P.e.), Aplysia californica (A.c.), Elysia crispata (E.c.), Biomphalaria glabrata (B.g.), Galba truncatula (G.t.), Limax maximus (L.m.), Cornu aspersum (C.a.), Helix pomatia (H.p.), Alinda biplicata (A.b.), Arion vulgaris (A.v.), Patella vulgata (P.v.), Neritina pulligera (N.p.), Titiscania limacina (T.l.). Verified presence of Biomphalaria glabrata conserved phytochelatin synthase domain by PCR shown in black rectangle.

Author Contributions: Conceptualization, R.D. and R.L.; methodology, R.L., R.D., M.D., and H.L.; software, R.L., M.D., P.L., L.K., and R.S.; validation, R.D., R.L., and H.L.; formal analysis, R.D., R.L., H.L., and M.D.; investigation, M.D., R.S., M.N., V.P.-M., R.L., and L.K.; resources, R.D. and H.L.; data curation, M.D.; writing-original draft preparation, M.D., L.K., R.L., and R.D.; writing-review and editing, all; visualization, M.D., R.D., and R.L.; supervision, R.L. and R.D.; project administration, R.D.; funding acquisition, R.D. and M.D. All authors have read and agreed to the published version of the manuscript.

Funding: This work was supported by project No. I 1482-N28 (DACH) of the Austrian Science Fund (FWF) granted to Reinhard Dallinger (University of Innsbruck). Martin Dvorak received support from project No. 219267 granted by HYPO Tirol Bank to, and from a doctorate scholarship No. 2017/2/Bio-3 of the University of Innsbruck. We thank to Thomas Ostermann (University of Innsbruck) with transcriptomes raw data assembly.

Conflicts of Interest: The authors declare no conflict of interest.

\section{References}

1. Oehlmann, J.; Schulte-Oehlmann, U. Molluscs as bioindicators. In Bioindicators E Biomonitors: Principles, Concepts, and Applications; Markert, B.A., Breure, A.M., Zechmeister, H.G., Eds.; Elsevier Science: Amsterdam, The Netherlands, 2002; pp. 577-635.

2. Dallinger, R.; Berger, B.; Triebskorn-Köhler, R.; Köhler, H.-R. Soil Biology and Ecotoxicology. In The Biology of Terrestrial Molluscs; Barker, G., Ed.; CAB International: Wallingford, UK, 2001; pp. 489-525.

3. Pedrini-Martha, V.; Schnegg, R.; Baurand, P.E.; deVaufleury, A.; Dallinger, R. The physiological role and toxicological significance of the non-metal-selective cadmium/copper-metallothionein isoform differ between embryonic and adult helicid snails. Comp. Biochem. Physiol. Part C Toxicol. Pharmacol. 2017, 199, $38-47$. [CrossRef] [PubMed]

4. Egg, M.; Höckner, M.; Brandstätter, A.; Schuler, D.; Dallinger, R. Structural and bioinformatic analysis of the Roman snail Cd-Metallothionein gene uncovers molecular adaptation towards plasticity in coping with multifarious environmental stress. Mol. Ecol. 2009, 18, 2426-2443. [CrossRef] [PubMed]

5. Capdevila, M.; Bofill, R.; Palacios, Ò.; Atrian, S. State-of-the-art of metallothioneins at the beginning of the 21st century. Coord. Chem. Rev. 2012, 256, 46-62. [CrossRef]

6. Kojima, Y. Definitions and nomenclature of metallothioneins. Methods Enzymol. 1991, 205, 8-10.

7. Kägi, J.H.R.; Schäffer, A. Biochemistry of Metallothionein. Biochemistry 1988, 27, 8509-8515. [CrossRef]

8. Meloni, G.; Zovo, K.; Kazantseva, J.; Palumaa, P.; Vasak, M. Organization and Assembly of Metal-Thiolate Clusters in Epithelium-specific Metallothionein-4*. J. Biol. Chem. 2006, 281, 14588-14595. [CrossRef] 
9. Kägi, J.H.R. Evolution, structure and chemical activity of class I metallothioneins: An overview. In Metallothionein III: Biological Roles and Medical Implications, Proceedings of the Metallothionein International Conference, 1992, Tsukuba, Japan; Birkhauser Verlag: Boston, MA, USA, 1993; Volume 3, pp. $29-56$.

10. Baumann, C.; Beil, A.; Jurt, S.; Niederwanger, M.; Palacios, O.; Capdevila, M.; Atrian, S.; Dallinger, R.; Zerbe, O. Structural Adaptation of a Protein to Increased Metal Stress: NMR Structure of a Marine Snail Metallothionein with an Additional Domain. Angew. Chem. Int. Ed. 2017, 56, 4617-4622. [CrossRef]

11. Schmielau, L.; Dvorak, M.; Niederwanger, M.; Dobieszewski, N.; Pedrini-Martha, V.; Ladurner, P.; Rodríguez-Guerra Pedregal, J.; Maréchal, J.D.; Dallinger, R. Differential response to cadmium exposure by expression of a two and a three-domain metallothionein isoform in the land winkle Pomatias elegans: Valuating the marine heritage of a land snail. Sci. Total Environ. 2019, 648, 561-571. [CrossRef]

12. Kägi, J.H.R. Overview of Metallothionein. Methods Enzymol. 1991, 205, 613-626.

13. Roesijadi, G. Metallothionein Induction as a Measure of Response to Metal Exposure in Aquatic Animals. Environ. Health Perspect. 1994, 102, 91-95. [CrossRef]

14. Klaassen, C.D.; Liu, J.; Diwan, B.A. Metallothionein protection of cadmium toxicity. Toxicol. Appl. Pharmacol. 2009, 238, 215-220. [CrossRef] [PubMed]

15. Stillman, M.J.; Zelazowski, A.J. Domain-specificity of $\mathrm{Cd}^{2+}$ and $\mathrm{Zn}^{2+}$ binding to rabbit liver metallothionein 2. Biochem. J. 1989, 262, 181-188. [CrossRef] [PubMed]

16. Li, H.; Otvos, J.D. 111Cd NMR Studies of the Domain Specificity of $\mathrm{Ag}^{+}$and $\mathrm{Cu}^{+}$Binding to. Biochemistry 1996, 35, 13929-13936. [CrossRef] [PubMed]

17. Tio, L.; Villarreal, L.; Atrian, S.; Capdevila, M. Functional Differentiation in the Mammalian Metallothionein. J. Biol. Chem. 2004, 279, 24403-24413.

18. Kägi, J.H.R.; Kojima, Y. Chemistry and biochemistry of metallothionein. In Metallothionein II. Experientia Supplementum 52; Kägi, J.H.R., Kojima, Y., Eds.; Birkhäuser Verlag: Basel, Switzerland, 1987; Volume 52, pp. 25-61.

19. Vasak, M. Standard Isolation Procedure for Metallothioneins. Methods Enzymol. 1991, 205, 41-44. [PubMed]

20. Krężel, A.; Maret, W. The functions of metamorphic metallothioneins in zinc and copper metabolism. Int. J. Mol. Sci. 2017, 18, 1237. [CrossRef]

21. Dallinger, R.; Berger, B.; Hunziker, P.; Kägi, J.H.R. Metallothionein in snail Cd and Cu metabolism. Nature 1997, 388, 237-238. [CrossRef]

22. Palacios, Ò.; Pagani, A.; Pérez-Rafael, S.; Egg, M.; Höckner, M.; Brandstätter, A.; Capdevila, M.; Atrian, S.; Dallinger, R. Shaping mechanisms of metal specificity in a family of metazoan metallothioneins: Evolutionary differentiation of mollusc metallothioneins. BMC Biol. 2011, 9, 4. [CrossRef]

23. Benito, D.; Niederwanger, M.; Izagirre, U.; Dallinger, R.; Soto, M. Successive onset of molecular, cellular and tissue-specific responses in midgut gland of Littorina littorea exposed to sub-lethal cadmium concentrations. Int. J. Mol. Sci. 2017, 18, 1815. [CrossRef]

24. Gonçalves, S.F.; Davies, S.K.; Bennett, M.; Raab, A.; Feldmann, J.; Kille, P.; Loureiro, S.; Spurgeon, D.J.; Bundy, J.G. Sub-lethal cadmium exposure increases phytochelatin concentrations in the aquatic snail Lymnaea stagnalis. Sci. Total Environ. 2016, 568, 1054-1058.

25. Blum, R.; Beck, A.; Korte, A.; Stengel, A.; Letzel, T.; Lendzian, K.; Grill, E. Function of phytochelatin synthase in catabolism of glutathione-conjugates. Plant J. 2007, 49, 740-749. [CrossRef] [PubMed]

26. Giovanelli, J.; Mudd, S.H.; Datko, A.H. Sulfur Amino Acids in Plants. In The Biochemistry of Plants; Academic Press, Inc.: Cambridge, MA, USA, 1980; Volume 5, pp. 453-505.

27. Kawakami, S.K.; Gledhill, M.; Achterberg, E.P. Determination of phytochelatins and glutathione in phytoplankton from natural waters using HPLC with fluorescence detection. Trends Anal. Chem. 2006, 25, 133-142. [CrossRef]

28. Cobbett, C.S. Phytochelatins and Their Roles in Heavy Metal Detoxification. Plant Physiol. 2000, 123, 825-832. [CrossRef] [PubMed]

29. Bundy, J.G.; Kille, P.; Liebeke, M.; Spurgeon, D.J. Metallothioneins may not be enough-The role of phytochelatins in invertebrate metal detoxification. Environ. Sci. Technol. 2014, 48, 885-886. [CrossRef]

30. Clemens, S.; Schroeder, J.I.; Degenkolb, T. Caenorhabditis elegans expresses a functional phytochelatin synthase. Eur. J. Biochem. 2001, 268, 3640-3643. [CrossRef]

31. Vatamaniuk, O.K.; Bucher, E.A.; Ward, J.T.; Rea, P.A. A new pathway for heavy metal detoxification in animals. Phytochelatin synthase is required for cadmium tolerance in Caenorhabditis elegans. J. Biol. Chem. 2001, 276, 20817-20820. [CrossRef] 
32. Bundy, J.G.; Kille, P. Metabolites and metals in Metazoa-what role do phytochelatins play in animals? Metallomics 2014, 6, 1576-1582. [CrossRef]

33. Dallinger, R.; Berger, B.; Gruber, C.; Hunziker, P.; Sturzenbaum, S. Metallothioneins in terrestrial invertebrates: Structural aspects, biological significance and implications for their use as biomarkers. Cell. Mol. Biol. 2000, 46, 331-346.

34. Dallinger, R.; Chabicovsky, M.; Berger, B. Isoform-specific quantification of metallothionein in the terrestrial gastropod Helix pomatia I. Molecular, biochemical, and methodical background. Environ. Toxicol. Chem. 2004, 23, 890-901. [CrossRef]

35. Chabicovsky, M.; Klepal, W.; Dallinger, R. Mechanisms of cadmium toxicity in terrestrial pulmonates: Programmed cell death and metallothionein overload. Environ. Toxicol. Chem. 2004, 23, 648-655. [CrossRef]

36. Palacios, Ò.; Jiménez-Martí, E.; Niederwanger, M.; Gil-Moreno, S.; Zerbe, O.; Atrian, S.; Dallinger, R.; Capdevila, M. Analysis of metal-binding features of the wild type and two domain-truncated mutant variants of Littorina littorea metallothionein reveals its cd-specific character. Int. J. Mol. Sci. 2017, 18, 1452. [CrossRef] [PubMed]

37. Niederwanger, M.; Dvorak, M.; Schnegg, R.; Pedrini-martha, V.; Bacher, K.; Bidoli, M.; Dallinger, R. Challenging the Metallothionein (MT) Gene of Biomphalaria glabrata: Unexpected Response Patterns Due to Cadmium Exposure and Temperature Stress. Int. J. Mol. Sci. 2017, 18, 1747. [CrossRef] [PubMed]

38. Gnatyshyna, L.; Falfushynska, H.; Bodilovska, O.; Oleynik, O.; Golubev, A.; Stoliar, O. Metallothionein and glutathione in Lymnaea stagnalis determine the specificity of responses to the effects of ionising radiation. Radioprotection 2012, 47, 231-242. [CrossRef]

39. Dvorak, M.; Lackner, R.; Niederwanger, M.; Rotondo, C.; Schnegg, R.; Ladurner, P.; Pedrini-Martha, V.; Salvenmoser, W.; Kremser, L.; Lindner, H.; et al. Metal binding functions of metallothioneins in the slug Arion vulgaris differ from metal-specific isoforms of terrestrial snails. Metallomics 2018, 10, 1638-1654. [CrossRef]

40. Niederwanger, M.; Calatayud, S.; Zerbe, O.; Atrian, S.; Albalat, R.; Capdevila, M.; Palacios, Ò.; Dallinger, R. Biomphalaria glabrata metallothionein: Lacking metal specificity of the protein and missing gene upregulation suggest metal sequestration by exchange instead of through selective binding. Int. J. Mol. Sci. 2017, 18, 1457. [CrossRef]

41. Romiguier, J.; Gayral, P.; Ballenghien, M.; Bernard, A.; Cahais, V.; Chenuil, A.; Chiari, Y.; Dernat, R.; Duret, L.; Faivre, N.; et al. Comparative population genomics in animals uncovers the determinants of genetic diversity. Nature 2014, 515, 261-263. [CrossRef]

42. Grill, E.; Löffler, S.; Winnacker, E.-L.; Zenk, M.H. Phytochelatins, the heavy-metal-binding peptides of plants, are synthesized from glutathione by a specific $\gamma$-glutamylcysteine dipeptidyl transpeptidase (phytochelatin synthase). Proc. Natl. Acad. Sci. USA 1989, 86, 6838-6842. [CrossRef]

43. Ha, S.; Smith, A.P.; Howden, R.; Dietrich, W.M.; Bugg, S.; O'Connell, M.J.; Goldsbrough, P.B.; Cobbett, C.S. Phytochelatin Synthase Genes from Arabidopsis and the Yeast Schizosaccharomyces pombe. Plant Cell 1999, 11, 1153-1163. [CrossRef]

44. Rodrigo, M.A.M.; Anjum, N.A.; Heger, Z.; Zitka, O.; Vojtech, A.; Pereira, E.; Kizek, R. Role of Phytochelatins in Redox Caused Stress in Plants and Animals. In Agricultural and Biological Sciences "Abiotic and Biotic Stress in Plants—Recent Advances and Future Perspectives"; Shanker, A.K., Shanker, C., Eds.; IntechOpen Ltd.: London, UK, 2016.

45. Dennis, K.K.; Uppal, K.; Liu, K.H.; Ma, C.; Liang, B.; Go, Y.-M.; Jones, D.P. Phytochelatin database: A resource for phytochelatin complexes of nutritional and environmental metals. Database 2019, 2019, 1-9. [CrossRef]

46. Chabicovsky, M.; Niederstätter, H.; Thaler, R.; Hödl, E.; Parson, W.; Rossmanith, W.; Dallinger, R. Localization and quantification of $\mathrm{Cd}$ - and $\mathrm{Cu}$-specific metallothionein isoform mRNA in cells and organs of the terrestrial gastropod Helix pomatia. Toxicol. Appl. Pharmacol. 2003, 190, 25-36. [CrossRef]

47. Chekmeneva, E.; Prohens, R.; Díaz-Cruz, J.M.; Ariño, C.; Esteban, M. Competitive Binding of Cd and Zn with the Phytochelatin ( $\gamma$-Glu-Cys)4-Gly: Comparative Study by Mass Spectrometry, Voltammetry-Multivariate Curve Resolution, and Isothermal Titration Calorimetry. Environ. Sci. Technol. 2008, 42, 2860-2866. [CrossRef] [PubMed]

48. Viarengo, A.; Ponzano, E.; Dondero, F.; Fabbri, R. A Simple Spectrophotometric Method for Metallothionein Evaluation in Marine Organisms: An Application to Mediterranean and Antarctic Molluscs. Mar. Environ. Res. 1997, 44, 69-84. [CrossRef] 
49. Wepener, V.; van Vuren, J.H.J.; Chatiza, F.P.; Mbizi, Z.; Slabbert, L.; Masola, B. Active biomonitoring in freshwater environments: Early warning signals from biomarkers in assessing biological effects of diffuse sources of pollutants. Phys. Chem. Earth 2005, 30, 751-761. [CrossRef]

50. Brown, R.J.; Galloway, T.S.; Lowe, D.; Browne, M.A.; Dissanayake, A.; Jones, M.B.; Depledge, M.H. Differential sensitivity of three marine invertebrates to copper assessed using multiple biomarkers. Aquat. Toxicol. 2004, 66, 267-278. [CrossRef]

51. Ureña, R.; Bebianno, M.J.; del Ramo, J.; Torreblanca, A. Ecotoxicology and Environmental Safety Metallothionein in the freshwater gastropod Melanopsis dufouri chronically exposed to cadmium: A methodological approach. Ecotoxicol. Environ. Saf. 2010, 73, 779-787. [CrossRef]

52. Scheuhammer, A.M.; Cherian, M.G. Quantification of Metallothionein by Silver Saturation. Methods Enzymol. 1991, 205, 78-83.

53. Leung, K.M.Y.; Ibrahim, H.; Dewhurst, R.E.; Morley, N.J.; Crane, M.; Lewis, J.W. Concentrations of Metallothionein-Like Proteins and Heavy Metals in the Freshwater Snail Lymnaea stagnalis Exposed to Different Levels of Waterborne Cadmium. Bull. Environ. Contam. Toxicol. 2003, 71, 1084-1090. [CrossRef]

54. Leung, K.M.Y.; Furness, R.W. Induction of Metallothionein in Dogwhelk Nucella lapillus during and after Exposure to Cadmium. Ecotoxicol. Environ. Saf. 1999, 43, 156-164. [CrossRef]

55. Leung, K.M.Y.; Svavarsson, J.; Crane, M. Influence of static and fluctuating salinity on cadmium uptake and metallothionein expression by the dogwhelk Nucella lapillus (L.). J. Exp. Mar. Bio. Ecol. 2002, 274, 175-189. [CrossRef]

56. Berger, B.; Dallinger, R.; Thomaser, A. Quantification of metallothionein as a biomarker for cadmium exposure in terrestrial gastropods. Environ. Toxicol. Chem. 1995, 14, 781-791. [CrossRef]

57. Dallinger, R.; Lagg, B.; Egg, M.; Schipflinger, R.; Chabicovsky, M. Cd accumulation and Cd-metallothionein as a biomarker in Cepaea hortensis (Helicidae, Pulmonata) from laboratory exposure and metal-polluted habitats. Ecotoxicology 2004, 13, 757-772. [CrossRef] [PubMed]

58. Siboni, N.; Fine, M.; Bresler, V.; Loya, Y. Coastal coal pollution increases Cd concentrations in the predatory gastropod Hexaplex trunculus and is detrimental to its health. Mar. Pollut. Bull. 2004, 49, 111-118. [CrossRef] [PubMed]

59. Downs, C.A.; Dillon, R.T.J.; Fauth, J.E.; Woodley, C.M. A molecular biomarker system for assessing the health of gastropods (Ilyanassa obsoleta) exposed to natural and anthropogenic stressors. J. Exp. Mar. Biol. Ecol. 2001, 259, 189-214. [CrossRef]

60. Pedrini-Martha, V.; Niederwanger, M.; Kopp, R.; Schnegg, R.; Dallinger, R. Physiological, diurnal and stress-related variability of cadmium-metallothionein gene expression in land snails. PLoS ONE 2016, 11, 1-19. [CrossRef]

61. Grabherr, M.G.; Haas, B.J.; Yassour, M.; Levin, J.Z.; Thompson, D.A.; Amit, I.; Adiconis, X.; Fan, L.; Raychowdhury, R.; Zeng, Q.; et al. Full-length transcriptome assembly from RNA-Seq data without a reference genome. Nat. Biotechnol. 2011, 29, 644-652. [CrossRef]

62. Zhang, Z.; Schwartz, S.; Wagner, L.; Miller, W. A greedy algorithm for aligning DNA sequences. J. Comput. Biol. 2000, 7, 203-214. [CrossRef]

63. Morgulis, A.; Coulouris, G.; Raytselis, Y.; Madden, T.L.; Agarwala, R.; Schäffer, A.A. Database Indexing for Production MegaBLAST Searches. Bioinformatics 2008, 24, 1757-1764. [CrossRef]

(C) 2019 by the authors. Licensee MDPI, Basel, Switzerland. This article is an open access article distributed under the terms and conditions of the Creative Commons Attribution (CC BY) license (http://creativecommons.org/licenses/by/4.0/). 